\title{
DEFINING LAW TERMS: A CROSS-CULTURAL PERSPECTIVE
}

\author{
ANNA JOPEK-BOSIACKA \\ a.jopek-bosiacka@uw.edu.pl \\ Institute of Applied Linguistics, University of Warsaw, Poland
}

\begin{abstract}
Legal definitions are vital for effective legal communication. This paper outlines main conventions of formulating definitions in statutes and contracts. Legal definitions are analyzed here from cross-cultural perspective against (legislative) drafting guidelines and theory of law. Their formulation may depend, inter alia, on legal system, branch of law, legal genre, position within the document, and type of legal definition.

An attempt is then made to examine how formal aspects of formulating legal definitions may affect the interpretation and thus translation of law terms. This interdisciplinary cross-cultural examination provides a theoretical basis for sketching main approaches to English-Polish (Polish-English) translation of the definition section in ratified international instruments published in Polish Journal of Laws.

The translation practice trends towards legal definitions seem to be more and more informed by the globalization and 'Europeanisation' processes now constituting a still broader context of legal communication rather than confined to the text of a legal instrument itself.
\end{abstract}

Key words: legal definition, law term, cross-cultural communication, legal translation

\section{Introduction}

Legal definitions are vital to the operation of legal instruments. The majority of legal definitions, aimed at unambiguous and consistent interpretation of legal texts, are set forth in such legal genres as statutes and contracts.

The focus of this paper is to explore the main principles and conventions of formulating definitions from cross-cultural perspective. In particular, their formulation may be determined by such factors as:

- type of legal genre (statutes vs. contracts);

- position in the instrument (preliminary provisions vs. principal provisions);

- type of legal definition (e.g. intensional definitions vs. extensional definitions);

- legal system (civil law vs. common law jurisdictions);

- branch of law (e.g. civil law vs. criminal law).

Following systematized introduction into formal aspects of formulating legal definitions, the interpretation and translation facets will be explored. This paper will particularly involve an attempt to examine the extent to which the discussed aspects inform the interpretation and thus translation of law terms. 


\section{Law terms}

Every term in specialized language (LSP - language for special purposes) signals a concept and "condenses the semantic value contributed by the defining process which generated it" (Gotti 2003: 33).

Legal definitions refer to words signifying the concepts in law as the language of law - belonging to the group of specialized languages - consists of technical or legal terms, as well as non-technical terms from ordinary language (see Gémar 1995-II: 96; also Cornu 1990: 61-65). Numerous terms used in legal discourse derive their general meaning from ordinary language (e.g. thing, property, theft, rent) but are assigned a special legal meaning by each legal system (so-called 'common words with uncommon meaning' - Danet 1980). In fact, words from ordinary language without change in meaning cannot be treated as law terms, even if their meaning is reconstructed in a legal definition (Malinowski 2006: 154).

The development of legal terminology in common law system has been influenced to a great extent by jurisprudence. In the common law, terms, phrases, even whole chunks of discourse, mean what courts have decided they mean.

For example, most people would recognize the dictionary definition of the term „heir”, as

a person who will legally receive money, property or a title from another person, esp. an older member of the same family, when that other person dies

(Cambridge International Dictionary of English, 1997, Cambridge: Cambridge University Press, p. 660).

However, the strict legal definition of „heir” differs in important ways from the common dictionary definition. According to Black's Law Dictionary, an "heir" is a person who, under the laws of intestacy, is entitled to receive an intestate decedent's property, esp. real property (1999: 727; meaning 1).

Laymen-and sometimes first-year law students taking exams-wrongly assume that one who receives real property by will is an heir. Technically, the word "heir" is reserved for one who receives real property by action of the laws of intestacy [...] (T. F. Bergin \& P. G. Haskell, Preface to Estates in Land and Future Interests, 14 no. 32, 2d ed. 1984, quoted in Black's Law Dictionary, 1999: 727).

Similarly, under the Polish law: the Act on Inland Fishery (ustawa o rybactwie śródladowym) of 18 April 1985 (uniform text, Dz.U. No. 66/1985, item 750, as amended) governs the principles and conditions of fish breeding, farming and fishery in surface inland waters pursuant to art. 1.1. However, art. 2.1. thereof provides that the Act's provisions shall apply respectively to the conditions of breeding, farming, and fishing of crayfish and lampreys. Thus, under the Polish Act on Inland Fishery a crayfish is fish.

Other examples of terms with a strict legal definition built on precedent are "assault" and "battery". In the middle ages, these terms were given technical meanings which they have retained ever since. It became settled that, contrary to ordinary usage, an assault does not require physical contact, an intention in one person which produces a fear in 
another is sufficient. Also, a "battery" does not require an actual beating, the use of any degree of force against the body would suffice, for example, spitting on a person, or kissing without consent (A. H. Loewy, 1987, Criminal Law in a Nutshell, 2d ed., quoted in Black's Law Dictionary, 1999: 109; see also Charrow et al. 1982: 185). V. R. Charrow, J. A. Crandall, R. P. Charrow mention more examples of terms whose meanings have been established through the legal process, with little regard to the everyday meaning of the term, such as "purchase", "domicile" or "adultery" (Charrow et al. 1982: 185).

Table 1. Ordinary vs. legal meaning

\begin{tabular}{|c|c|c|}
\hline & ordinary meaning & legal meaning \\
\hline assault & 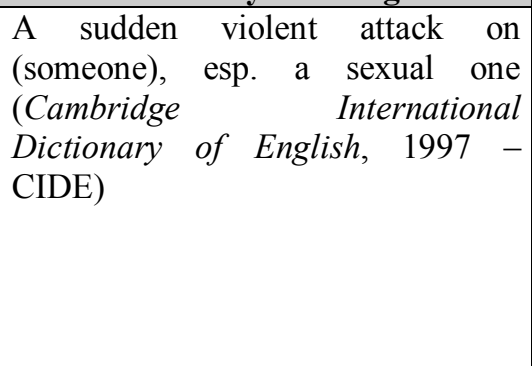 & $\begin{array}{l}\text { 1. (criminal \& tort law) the threat } \\
\text { or use of force on another that } \\
\text { causes that person to have a } \\
\text { reasonable apprehension of an } \\
\text { immediate battery by means of an } \\
\text { act amounting to an attempt or } \\
\text { threat to commit a battery } \\
\text { (Black's Law Dictionary } 1999 \text { - } \\
\text { BLD) }\end{array}$ \\
\hline battery & $\begin{array}{l}\text { to batter }- \text { to hit and behave } \\
\text { violently towards (a person, esp. a } \\
\text { woman or child) repeatedly over a } \\
\text { long period of time (CIDE) }\end{array}$ & $\begin{array}{l}\text { 1. (criminal law) the application } \\
\text { of force to another, resulting in } \\
\text { harmful or offensive contact } \\
2 \text {. (torts) an intentional and } \\
\text { offensive touching of another } \\
\text { without lawful justification } \\
\text { (BLD) }\end{array}$ \\
\hline purchase & $\begin{array}{l}\text { 1. thing(s) you have bought } \\
\text { 2. an/the act of buying (CIDE) }\end{array}$ & $\begin{array}{l}\text { 1. the act or an instance of buying } \\
\text { 2. the acquisition of real property } \\
\text { by one's own or another's act(as } \\
\text { by will or gift) rather that by } \\
\text { descent or inheritance (BLD) }\end{array}$ \\
\hline domicile & $\begin{array}{l}\text { the place where a person lives } \\
\text { (CIDE) }\end{array}$ & $\begin{array}{l}\text { 1. the place at which a person is } \\
\text { physically present and that the } \\
\text { person regards as home; a } \\
\text { person's true, fixed, principal, } \\
\text { and permanent home, to which } \\
\text { that person intends to return and } \\
\text { remain even though currently } \\
\text { residing elsewhere } \\
\text { 2. the residence of a person or } \\
\text { corporation for legal purposes } \\
\text { (BLD) }\end{array}$ \\
\hline
\end{tabular}




\begin{tabular}{|l|l|l|}
\hline & \multicolumn{1}{|c|}{ ordinary meaning } & \multicolumn{1}{c|}{ legal meaning } \\
\hline \multirow{3}{*}{ adultery } & $\begin{array}{l}\text { sex between a married man or } \\
\text { woman and someone who is not } \\
\text { their wife or husband (CIDE) }\end{array}$ & $\begin{array}{l}\text { voluntary sexual intercourse } \\
\text { between a married person and a } \\
\text { person other than the offender's } \\
\text { spouse (BLD) } \\
\text { cf. different definitions in different } \\
\text { American states (also fornication) }\end{array}$ \\
\hline
\end{tabular}

Elaborating on the last example in Table 1, the comparison of legal definitions of the term "adultery" in various legal systems and jurisdictions and cultures shows interesting differences. In the Anglo-Saxon common law system, 'adultery' is regulated by the written statutory law. In England "adultery" referred to sex by a married person with someone other than the spouse belongs to the branch of criminal law, but is recognized as an offence only in the ecclesiastical court (Black's Law Dictionary 1999: 52). In the United States, the differences in interpretation depend on the state. In some states, sexual intercourse between two married persons, who are not married to each other, constitutes adultery on the part of both. Sexual intercourse between a married person and an unmarried person likewise constitutes adultery on the part of both. In other states, adultery can be committed only by a married person. Thus, sexual intercourse between two married persons who are not married to each other constitutes adultery on the part of both. But if only one party to the sexual intercourse is married, the intercourse constitutes adultery on the part of the married person and "fornication" on the part of the unmarried person. "Fornication" i.e. a voluntary sex intercourse between two unmarried persons is not a common-law crime but was made punishable by statute in a few states as a misdemeanour. However, in some states such as Virginia it is recognized as a crime (Black's Law Dictionary 1999: 664). There are also some gender differences. In some states, adultery is committed only where the woman is the married party. Thus, sexual intercourse between a married woman and a married man other than her spouse or sexual intercourse between a married woman and an unmarried man constitutes adultery on the part of both, but if the woman is unmarried, neither party is guilty of adultery even if the man is married (Black's Law Dictionary 1999: 52).

In the Polish law as an instance of the continental civil system, adultery is not subject to legal regulations. According to legal doctrine (Ignatowicz 1987: 138), it only constitutes a ground for divorce in the circumstances of absolute and irretrievable breakdown of marriage pursuant to art. 56 of the Family and Guardianship Code (Kodeks rodzinny $i$ opiekuńczy) of 1964 as amended and referred to as the conjugal infidelity (zdrada matzeńska) but not in the statutory text itself.

\subsection{Nature and formation}

The process of formation of legal terms, especially those not belonging to common speech, may take place in a number of ways.

Most legal terms are short-cuts - adaptations of English to serve the functional needs of practising lawyers, i.e. to label new doctrines, problems and institutions (Friedman 
1964: 565). Some are adaptations of common words to specialized meanings, conceptually related to the core meaning of the word in common speech, such as "offer" and "acceptance" in contract law. Some are coined by lawyers and draftsmen specifically to cover a new concept, especially in developing branches of law as in case of the tax or banking law. An example would be "prudential supervision" in the EU law, the Polish equivalent is equally awkward - "nadzór ostrożnościowy". Others are handy and catchy metaphors, such as "piercing the corporate veil" (i.e. "the judicial act of imposing personal liability on otherwise immune corporate officers, directors, and shareholders for the corporation's wrongful acts" - Black's Law Dictionary 1999: 1168). Many of these terms are used by lawyers for the sake of brevity and efficiency, even though the layman understands and is familiar with the underlying concept. Lawyers use such term as a kind of shorthand, e.g. the "blue law", which used to be a statute regulating or prohibiting commercial activity on Sundays (Black's Law Dictionary 1999: $165)$.

Other terms are "technical" in a stricter sense; they pertain to definite concepts and institutions which do not exist outside the law. Examples of these are endless: easement, negligence, legal capacity, joint stock company, etc. (cf. Lampe 1970: 28). Their use is as natural and unavoidable to the profession as the use of "calcium fluoride" or "semiconductor" in other fields.

There exist two views as to the nature of legal terms: polysemic, i.e. contextdependent represented mostly by linguists (Cornu 1990; Gémar 1995; Joseph 1995; Roszkowski 1999), and deterministic view held by lawyers (Kelsen 1967; Hart 1961; MacCormick 1974; Sarkowicz 1995). According to linguists, terms of the exact sciences are monosemous, i.e. each term refers to only one object, whereas legal terms are characterized by polysemy (see Cornu 1990: 89-117; Gémar 1995-II: 130). The phenomenon of polysemy requires, on the one hand, the necessity to determine the intended meaning from the context. On the other hand, the fact that most legal terms derive their meaning from a particular legal system makes legal terminology inherently congruent (cf. Šarčević 1997: 231).

The multitude of legal systems existing in the world leads to the frequent situation that a concept in one legal language does not have a corresponding equivalent in another or a concept exists in both legal concepts but it denotes different legal realities. In short, the inadequacy of equivalents or their lack along with polysemy can be considered the major obstacle on the way to achieving the precision of legal language particularly in the context of translating texts or using the banks of legal terms expressed in various world languages. Due to normative function of legal discourse, legal concepts automatically imply certain legal effects within a given system (see Lampe 1970: 25).

There have been many attempts made by linguists and philosophers to define the concept of meaning in such a way that the meaning would be objective, supracontextual, independent of any circumstances (see e.g. R. W. Burch's differentiation between 'meaning in isolation' and 'meaning in use' - 1973; Stanosz 1973; Wunderlich 1980). Such attempts to shape the non-contextual meaning were often linked with the socalled literal meaning that is the meaning defined in the null context (zero context, neutral context). The researchers though failed to model the meaning without the context (see critical voices e.g. Searle 1980: 221-232). 
Obviously, according to contemporary assumptions of researchers, the meaning of a word is partly dependent on the prior experiences of the language user (Barsalou 1992: 34; Wichter 1994: 90; Bromme and Bünder 1994), which have been called by Sigurd Wichter as (partial) determination of meaning by prior experience (in Jan Engberg's translation 2000: 34). Rainer Bromme and Wolfgang Bünder (1994) suggest that through experience everyday meaning is enriched and transformed into expert meaning which is one of many possible approaches ( $c f$. Jahr 1993; Wichter 1994; see also discussion in Engberg 2000: 32-34), but the one which matches the historical development of legal discourse. The difference between everyday and expert meaning can be explained by existence of different legal genres.

\subsection{Interpretation}

The interpretation of legal meaning differs from, for example, literary interpretation. $\mathrm{T}$. S. Eliot once said that the interpretation of a reader might be much different than the author's interpretation, and may be as right, or maybe even more accurate (1972: 22; see also Gadamer's notion of Anders-Verstehen referred to texts of the arts and social sciences, 1975: 280). Unlike the literary interpretation but close to biblical interpretation, the interpretation of legal texts is based on the assumption that it has one adequate meaning (Sarkowicz 1995: 91). The opposite assumption would make it impossible for the court or the administrative body to pass any decision or judgment. Of course such ideal understanding of legal meaning does not exclude the frequent problems with interpretation of legal texts, as the only meaning embodied in the text may not be the same for all addressees.

The construction of a legal text seems to impose certain limits on the text interpretation. The meaning in the legal text depends less on parameters of communication and more - on generally recognised by legal sciences principles of interpretation. Additionally, the explicit nature of a legal text as well as semantic accuracy in the world of legal text maximally diminishes the possible ways of interpretation. It is assumed that in any legal text the same words possess the same meaning, and if there are different words, they have been used intentionally to assign to them different meanings. The drafting of legislation and other legal acts, as framed by legal tradition, is assumed to be as precise and accurate as possible.

Various methods of interpretation have been developed in order to describe the sources that the interpreter may exploit so as to establish the meaning of the text (the wording of the text, the purpose of the text, the intention of the writer, the framework of other texts of which the interpreted text is a part, etc.). For a detailed description, see, for example, Ian McLeod (1993: 211-273) and Dietrich Busse (1992: 13-30). It should also be noted that the methods of interpretation vary for different types of legal texts, so the interpretation of contracts (see e.g. Lewison 1987: 1-7) will differ from the interpretation of statutes (e.g. Holland and Webb 2006: 227-267). Moreover, the methods of interpreting legislative texts also differ from jurisdiction to jurisdiction.

The standpoint that the clear meaning is fully determinate originates in its contemporary form from the positivist legal theorists, first of all Hans Kelsen, and is adhered to by H. L. A. Hart and D. N. MacCormick (1974: 102), who believed that law 
prescribes behaviour by means of a generic set of conventional meanings. The legal discourse is characterised by determinacy rather than polysemy. In Hart's (1958: 612) words,

\begin{abstract}
If we are to communicate with each other at all, and if, as in the most elementary form of law, we are to express our intentions that a certain type of behaviour be regulated by rules, then the general words we use ... must have some standard instance in which no doubts are felt about their application. There must be a core of settled meaning [...].
\end{abstract}

The conception of the systemic determination of legal key words was deemed to be the distinctive character of legal language, although recent developments in linguistics most particularly within sociolingustics and pragmatics prove that the analysis of the language of the law must take account of its socio-cultural extensions. The product of different institutions, history, culture, and sometimes socio-economic principles, each legal system has its own legal realia and thus its own conceptual system and even knowledge structure (Vanderlinden 1995: 328-337). Consequently, the legal terminology of different legal systems is, for the most part, conceptually incongruent (Šarčević 1989: 278; also Arntz 1993: 6). As a rule, conceptual differences are much greater between common law and civil law systems; however there are also notable differences between the corresponding concepts of individual civil law systems (Šarčević 1997: 245). In fact, these differences are so great that many comparative lawyers regard the 'romanistic' systems modeled on the French Civil Code and the 'germanic' systems which follow the German BGB as distinct legal families (Zweigert and Kötz 1984-I: 80).

The boundaries between the meanings of concepts of different legal systems are incongruent. The concept of décision in French law corresponds with two, more specific concepts in German law Entscheidung, Beschluss (Bauer-Bernet 1982: 192). Moreover, it appears that, within the same language, the same term designates different concepts in different legal systems. For instance, common-law marriage has one meaning in the U.S., another in Scotland, and still another in England (see Garner 2001: 179). In the United States, e.g. in Texas "common-law marriage" generally denotes an agreement to marry, followed by cohabitation and a public recognition of the marriage. In Scotland, the term denotes cohabitation for a substantial period with the acquisition of the reputation of being married (an agreement to marry not being necessary). And in England common-law marriage is now used only of a marriage celebrated according to a common-law form in a place where the local forms of marriage cannot be used (e.g. a desert island) or are morally unacceptable to the parties (e.g. a Muslim country) or where no cleric is available.

Even terms whose concepts have been directly transplanted into another legal system take on different meanings once the concepts have been assimilated into the foreign legal system and culture (so called "legal transplants" - see Watson 1974: 21). As a result, the civil law terminology in Turkey is not interpreted strictly in the sense of the Swiss ZGB although the latter was adopted almost word for word in the Turkish Civil Code of 1926 (Šarčević 1997: 232). Rich in transplants from French law (Code Napoléon), German law (BGB), and after 1945 the common law, is the law of Japan. The strict legal sense of the foreign concepts has been successfully assimilated into Japanese law; however, the historical, philosophical, and sociological connotations were lost in translation (Kitamura 1987: 787). Even general terms change their effective meaning when adopted 
by other legal systems. This was the case, for example, when terms such as family, land, person, wife, child, reasonable, etc. were transposed from England to the developing legal systems of Africa (see Allott 1974: 134). The family there may mean the major part of the tribe.

In addition, all legal systems contain a number of terms with no comparable counterparts in other legal systems or families (Šarčević 1997: 233). This is due to the fact that the actual object, relationship, action, or procedure does not exist in other legal systems. System-bound terms, as Susan Šarčević refers to them (1988: 455), designate concepts and institutions peculiar to the legal reality of a specific system or related systems. System-bound terms are frequently regarded as untranslatable ( $c f$. Šarčević 1997: 233; Allott 1974: 132). For the English-Polish translation we may mention such terms with no equivalent in the Polish legal system as trust, equity, consideration, estoppel. On the other hand, there are numerous indefinite or vague terms, such as the best interests of the child, due care and attention, and good faith, which are easily translated and already exist in most legal systems, but are interpreted differently by courts of different jurisdictions.

\section{Defining law terms}

In the first instance, legal language is marked by the precision of its lexicalization to achieve its superordinate goal - all-inclusiveness. It is exact meaning which distinguishes the 'term of art', and thus facilitates legal communication. On the semantic level, lawyers make attempts at precision of expression by careful choice of words and phrases. Indeed, "precision is the loudest virtue of the language of the law", as David Mellinkoff (1963: 399) once put it. In order for the law to function, the principle of semantic accuracy or language consistency must be observed. Once a technical term was selected, it must be repeated over and over again instead of using synonyms. The use of synonyms is discouraged in legal texts because the user might think that reference is being made to a different concept ( $c f$. Weston 1991: 32-33).

Legal definitions are today regarded mainly as aids for interpretation that promote clarity by reducing indeterminacy and help achieve consistency (Šarčević 1997: 153). Hence definitions are said to be among the most difficult provisions to draft (Rylance 1994: 137).

To mention cross-cultural differences, generally there are more definitions in common law than in civil law jurisdiction. The abundance of statutory definitions in common law jurisdictions may be viewed as a means of deliberately limiting judicial discretion, while civil law jurisdictions tend to encourage judges to use their own discretion (Wank 1985: 64).

\subsection{Types of legal definitions}

In philosophy, logic, and law, several different kinds of definitions are often in play, and definitions can serve a variety of different functions, first of all to enhance precision and clarity. 
I would like to make a reservation here that I would be taking positions of legal theory and logic rather than that of philosophy which imply my understanding of the definition itself and functionalist approach to the types of definitions discussed.

So let me begin by marking some preliminary but important distinctions. Although "definition" in common understanding can cover all sorts of clarifying utterances, I would accept the logicians' and lawyers' distinctions and discuss here some selected types of legal definitions, pertaining to the multilingual drafting of legal instruments and legal translation.

The first distinction may be made between Aristotelian concepts of "real" as opposite to "nominal" definitions. To put it simply, the "real" definition discloses what is important in the thing that is being defined, what elements constitute that thing. "Nominal" definitions, on the other hand, disclose the meaning of words. One main use of nominal definitions is lexical or reportive, which is concerned of what are the common or specific usages of words. In legal texts we only have nominal definitions that investigate the meaning and use of defined terms.

Table 2. Types of definitions according to the „point of reference” criterion

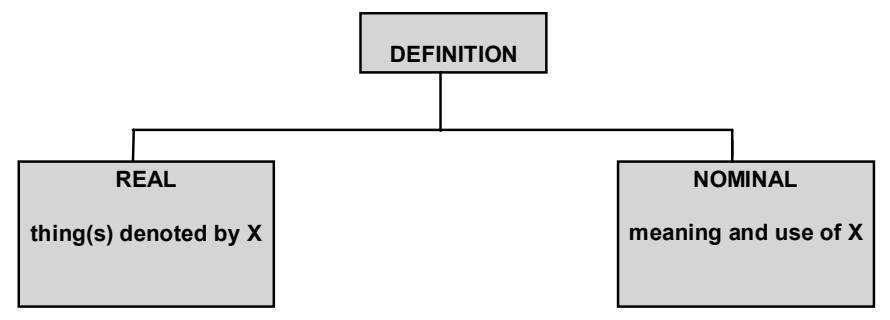

The second important distinction is based on the purpose of formulating a definition. Thus we may distinguish between descriptive definitions that are aimed at just documenting the current or past meaning and prescriptive definitions that assign a special meaning in law for future references. Vested with the force of law, statutory definitions are widely regarded as being prescriptive ( $c f$. Wank 1985: 65). We may subdivide prescriptive definitions into stipulative and explanatory definitions. While stipulative definitions alter "the ordinary meaning of words by narrowing or enlarging their sense or by creating a wholly new meaning for them" (Bowers 1989: 173), explanatory definitions "provide a necessary degree of definiteness" without altering conventional significations (Thornton 1987: 54). 
Table 3. Types of definitions according to the „purpose” criterion

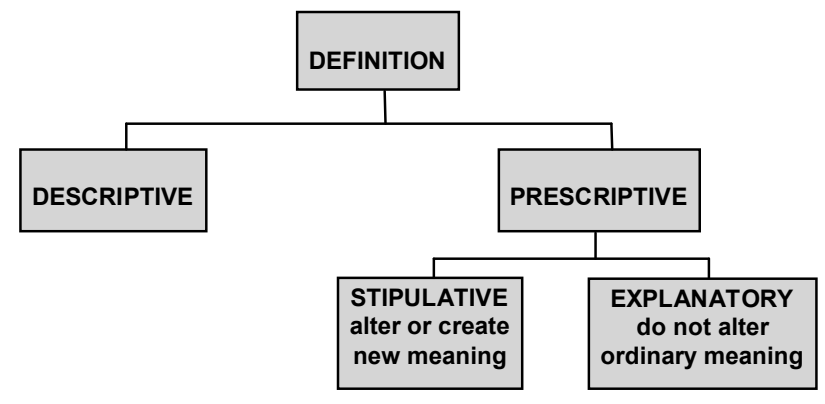

Of vital importance is the third disctinction of legal definitions that regards the structure of legal definition.

Table 4. Types of definitions according to the „structure” criterion

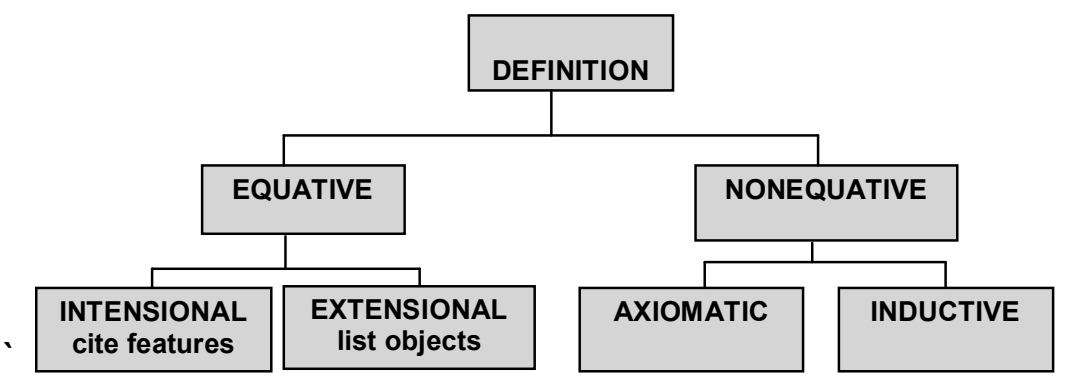

Equative definition composes of three parts: definiendum, defining connective, and definiens, as in Figure 1. 
Figure 1. Structure of equative definition

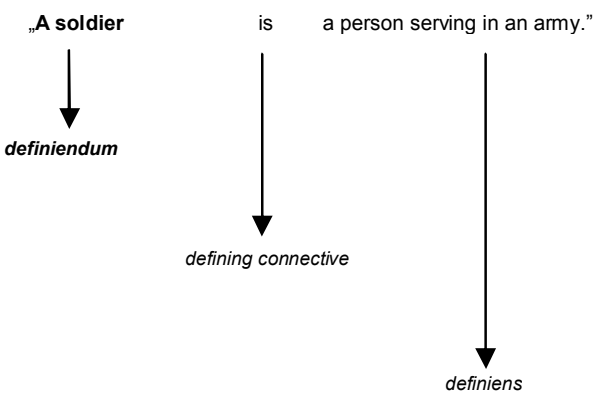

The standard form of the definition can be represented as follows:

in which "Soldier $=$ Df.

being defined, and "a person serving in the army........ definiens, that is, the expressions or concepts by means of which a term or concept is being defined. The definiendum can be replaced by the definiens and vice versa wherever the substitution is justified by the context, genre, etc. Thus, my understanding of the definition is similar to that of legal theoreticians (Stone 1964: 171; Ziembiński 1995, Malinowski 2006); so that the word "definition" means the whole "definitionformulation" not the definiens alone.

As Naess rightly observes,

The special merit of definition is not that it allows us to say more, but that because a definiendum is much shorter than a definiens and the latter contains a high level of preciseness [...]. (Naess 1966: 54, quoted after Gotti 2003: 34)

Legal equative definitions can be either intensional or extensional ( $c f$. Table 4). Equative definitions are used to denote those terms that are central to a given legal text (Zieliński 2002: 189, in Malinowski 2006: 166). And what is also important, in most equative definitions the definiendum is placed in the first position which eliminates possible ambiguity (Malinowski 2006: 167). While intensional definitions cite the essential features constituting the core sense of the definiendum, extensional definitions list the objects denoted and/or not denoted by the definiendum.

(a) Intensional definition

'Bank' means any person engaged in the business of banking.

[The US Uniform Commercial Code]

(b) Extensional definition

'fiduciary' means any person acting in a fiduciary capacity and includes a personal representative of a deceased person

[the Canadian Trust and Loan Companies Act [SC 1991]].

Whereas dictionary definitions of ordinary terms are primarily intensional, a large number of statutory definitions are extensional. Expressing logical relations, legal 
definitions set the limits of the definiendum by means of equivalence ( $\mathrm{X}$ means $\mathrm{Y}$ ), inclusion ( $\mathrm{X}$ includes $\mathrm{Y}$ ), and exclusion ( $\mathrm{X}$ does not include $\mathrm{Y}$ ) as well as of combinations of equivalence and inclusion ( $\mathrm{X}$ means $\mathrm{Y}$ and includes $\mathrm{Z}$ ) or equivalence and exclusion (X means Y but does not include Z).

The older practice of formulating intensional definitions in English with shall mean was replaced with the indicative means which is used in English texts today in accordance with the notion that the law is always speaking (Šarčević 1997: 153). While some researchers maintain that this change reduces the effectiveness of definitions considerably (e.g. Bowers 1989: 177), others point out that that the shall in older definitions did not impose an obligation to be obeyed or disobeyed but merely expressed an authoritative power of the lawmaker to create rules of law (e.g. Driedger 1976: 13).

The best and most frequent, we should say, practice nowadays, esp. in legislative texts is to use "means" for complete (intensional) definition, "includes" for a stipulated expansion in meaning (extensional definition), and "does not include" for a stipulated contraction of meaning (exclusion) (Garner 2001: 258). The most common way to signal terms in text is to use initial capitals, but also boldfacing and italicizing are sometimes used (Garner 2001: 258).

Among non-equative definitions ( $c f$. Table 4) we may distinguish axiomatic definitions that define the term in sample sentences, and inductive or recursive definitions that define an object in terms of itself, but these are less important from the point of view of translation and do not lie within the scope of interest of this article.

\subsection{Definitions and their location}

For the most part, the formulation of a definition is determined by its position in the instrument (Šarčević 1997: 153). For example, in Canadian legislation both explanatory and stipulative definitions are placed in the definition section of the preliminary provisions or, if they apply to a particular part of an act, in the principal provisions at the beginning of that part. In civil law legislation, definitions of ordinary terms are usually placed in a definition section in the preliminary provisions or following the general provisions, while definitions of technical terms are incorporated into the principal provisions (Šarčević 1997: 154). In both common law and civil law legislation, definitions in the definition section are formulated as definitions, whereas those appearing in the main body of the instrument usually take form of "real" provisions. Although they do not impose obligations or grant rights, definitions in the substantive provisions can be regarded as having a lawmaking function (Lampe 1970: 41).

Irrespective of the position in the instrument, an inherent element of each definition is its scope of application which may navigate the interpretation of a given term (Malinowski 2009: 304-305). Linguistically they take such forms as:

For the purpose(s) of this Act / of this part of the Act / of this paragraph

For the purpose of this Agreement

As used in this Agreement

Polish legislative drafting guidelines would determine similar expressions:

$W$ rozumieniu niniejszej ustawy określenie... oznacza... (Polish Legislative Drafting Guidelines - Zasady Techniki Prawodawczej - ZTP § 150) 
[literal translation: „As understood by this Act, the term “...” means ....] or

Ilekroć $w$ ustawie jest mowa o..., należy przez to rozumieć .... (ZTP § 148)

[literal translation: "Every time the term "..." is used, it shall be understood as ...".

As a rule, legal definitions incorporated into the principal provisions of legislative texts are formulated like 'real' definitions (Šarčević 1997: 156). Accordingly, inverted commas or italics are no longer used and the definiendum is not referred to as a term. Instead of means or includes, expressions such as is or is deemed to be are commonly used ( $c f$. Bowers 1989: 177). The following example cited by Frederick Bowers shows how the same definition would be formulated in the definition section and as a provision in the main body of the instrument:

In the definition section:

'pensionable age' means -

(a) in the case of a man, the age of 65

(b) in the case of a woman, the age of 60

In the principal provisions of the instrument:

The pensionable age of a man is the age of 65, and of a woman, the age of 60.

Definitions in the principal provisions contain descriptive material but have a lawmaking function in that they establish the legal criteria of terms (Šarčević 1997: 156).

\subsection{Definitions and branches of law}

A branch of law may also affect the formulation of a legal definition. In criminal provisions of common law legislation, it is frequent to define an offence or a crime by enumerating its constituent elements and situational components in an extended factsituation. For example, to determine in which situation the death of a newly born child qualifies as infanticide pursuant to the Canadian Criminal Code, the judge relies on the extensional definition of infanticide in the extended fact-situation in section 233:

A female person commits infanticide when by a wilful act or omission she causes the death of her newly-born child, if at the time of the act or omission she is not fully recovered from the effects of giving birth to the child and by reason thereof or of the effect of lactation consequent on the birth of the child her mind is then disturbed. (Section 233 of the Canadian Criminal Code; quoted after Šarčević 1997: 157).

The legal rule on infanticide is set forth in section 237 which reads as follows:

Every female person who commits infanticide is guilty of an indictable offence and liable to imprisonment for a term not exceeding five years.

(Section 237 of the Canadian Criminal Code; quoted after Šarčević 1997: 157). 
Contrary to Canadian legislation, in Polish criminal provisions legislators are discouraged to define crimes by referring to different articles of the Criminal Code ( $\S$ 75.1 of ZTP). Thus, art. 206 of the Polish Criminal Code would define bigamy in the following way:

A person who contracts marriage in spite of remaining in a marital union is subject to a fine, penalty of restriction of liberty or imprisonment for up to two years. (Art. 206 of the Polish Criminal Code)

A two-fold norm comprising the fact-situation and the statement of law are covered by a single legal provision.

Contrary to ordinary definitions, legal definitions are often negative, i.e. they define terms by specifying what they are not instead of what they are, for example, $\mathrm{X}$ is non- $\mathrm{Y}$. The Canadian Criminal Code gives the following negative definition of manslaughter: "Culpable homicide that is not murder or infanticide is manslaughter." (section 234 of the Canadian Criminal Code; quoted after Šarčević 1997: 157). This means that manslaughter is an act of culpable homicide that does not qualify as murder or infanticide pursuant to sections 231-233.

Similarly, according to $\S 75.3$ of Polish ZTP Guidelines, the negative forms in criminal law are expressly allowed, especially when referring to other provisions:

Nie popetnia przestępstwa określonego w art. ..., kto... .

[translation: A person shall not be liable for a crime under art. ...., if ...."]

Nie podlega karze za przestepstwo określone w art. ..., kto... .

[translation: "A person who committed a crime prescribed in art. ..., shall not be

liable to be punished, if ...".]

Legal definitions are also of vital importance in instruments of international law. The role of definitions seems to be decisive in promoting the uniform interpretation and application of international instruments. Since there is only a small number of international legal terms with a universally accepted signification (de Groot 1991: 283), thus it is essential that the parties agree on the signification and scope of terms and incorporate the definitions into the treaty or convention (Šarčević 1997: 158). This presupposes that the definitions contain no technical or other system-bound terms unknown in the legal systems of the signatory states.

This general rule is repeated in EU Joint Practical Guide (2003):

5.3.2. "[...] terms which are too closely linked to national legal systems should be avoided".

As in the case of other instruments, definitions pertaining to the whole instrument are usually placed in the definition section following the preamble, while definitions pertaining to a specific part are placed at the beginning of that part among the substantive provisions. 


\subsection{Drafting guidelines and theory of law - notes for translators}

The formal aspects of formulating statutory definitions are prescribed first of all in national or supranational (EU) legislative drafting, and additionally by the theory of law and logic. Statutory definitions facilitate adequate contact between a legislator and addressees of legal norms, as rightly observes Zieliński (2002: 188). Therefore, it is of paramount importance when translating legal texts that the terms used are equivalent and that the definition's formulation is adequate considering its type, location, etc.

The Polish legislative guidelines (ZTP) in $\S \S 146-154$ specify what connective forms are used in different types of statutory definitions, how expressions required for correct formulation of a definition are rendered in legislative Polish (e.g. "including but not limited to", "hereinafter referred to as", the title "definitions"), or what punctuation marks should be used. Unlike contractual definitions, statutory definitions are authoritative.

The Polish styleguide prepared by Polish staff at the Directorate General for Translation at the European Commission (version 5 of Feb. 2009) would only include intensional definitions, suggesting that the only connective form between the definiendum and the definiens is "mean" or "means":

"Customs authorities" means the authorities responsible inter alia for applying customs rules."

"Organy celne" oznaczają organy uprawnione między innymi do stosowania przepisów prawa celnego."

(VADEMECUM TŁUMACZA. Wskazówki redakcyjne dla thumaczy. Wersja 5 (luty 2009 r.); 2.1.3.8, DGT, Luxembourg)

The only practical thing the Vademecum focuses on is the singular or plural form of the verb "mean" dependent on the form of the defined term.

The formulation of contractual definitions is not subject to any legal provisions. The meaning of a contract term may depend on the usage of the trade, or on how the parties themselves used the term in past (Tiersma 2000: 116). The adherence to analogical rules when formulating statutory definitions in the case of contractual definitions (dependent on type, location, etc.) would be recommended, though not obligatory. Thus, we may see a variety of typographic solutions and translation strategies when translating, for example, a connective form. The non-authoritative nature of contractual definitions, and thus lack of official guidelines, might be the main reason for inconsistent translation of definitions included in multilingual international instruments ratified by Poland and published in the Polish Journal of Laws (see 4.2. below).

\subsection{Polish international instruments in translation - empirical analysis}

I conducted the qualitative analysis of a corpus of all international instruments published in the Polish official Journal of Laws in 2005 with attached Polish translations, such as 
conventions, treaties, agreements, and protocols. The corpus covered a total of 129 texts of international instruments. For the purpose of the analysis, I selected only those texts, where: (a) English was chosen as an authentic language (one of languages); (b) legal definition section or definitions in individual provisions were included. I found 101 such documents.

From the analysis of the corpus I have drawn the following conclusions:

* there are no universal conventions in formulating definitions in international instruments. They depend on the institution or authority that issued the document but even then there are some inconsistencies.

\section{Example 1}

The International Convention for the Safety of Life at Sea, 1974, would include two different principles of defining terms in the same Article 2 (italics vs. quotation marks and different style):

\section{" 2 DEFINITIONS}

For the purpose of this part, unless expressly provided otherwise:

$[\ldots]$

.9 Security level 1 means the level for which minimum appropriate protective measures shall be maintained at all times.

$[\ldots]$

2.3 The term "Contracting Government" in connection with any reference to a port facility, when used in sections 14 to 18 , includes a reference to the "Designated Authority"."

(Annex 1, Part A of The International Convention for the Safety of Life at Sea, 1974; Dz.U. 2005, No. 120, item 1016)

\section{Example 2}

"Article 1

1. For the purposes of this Convention:

(a) Alien means: any person other than a national of a Member State;

(b) $[\ldots] "$

(Convention determining the state responsible for asylum lodged in one of the Member States of the European Communities of 15 June 1990, Dz.U. 2005, 2005, No. 24, item 194).

The term is neither italicised nor put in inverted commas, the collon is used before the definiens. However, the Polish translation is rendered properly:

"cudzoziemiec" oznacza jakąkolwiek osobę inną niż obywatel Państwa Członkowskiego. 
$\underline{\text { Example } 3}$

\section{"Chapter I \\ Definitions and general provisions \\ Article 1}

For the purposes of this Convention:

a. "firearm" has the meaning assigned to it in Appendix I to this Convention;

b. "person" shall also mean a legal person having a place of business in the territory of a Contracting Party;

c. "dealer" means a person whose trade or business consists wholly or partly in the manufacture, sale, purchase, exchange or hire of firearms;

d. "resident" refers to a person who has habitual residence in the territory of a Contracting Party within the meaning of Rule 9 of the Annex to Resolution (72) 1 of the Committee of Ministers of the Council of Europe."

(European Convention on the control of the acquisition and possession of firearms by individuals of 28 June 1978; Dz.U. 2005, No. 189, item 1583)

Within art. 1, there are four conventions used to define the definiendum (term), the Polish translation would use two (b, c, d - "oznacza" (mean), a - "ma znaczenie" ("has the meaning").

* some unusual connective forms are used or no connective form is used, thus hindering the recognition of a proper definition type

Example 4

\section{"Part I}

\section{Scope and definitions}

Article 3

For the purpose of this Convention -

(a) the term "air pollution" covers all air contaminated by substances, whatever their physical state, which are harmful to health or otherwise dangerous";

(b)

(Art. 3 of Convention 148 concerning the protection of workers against occupational hazards in the working environment due to air pollution, noise and vibration of 20 June 1977, Dz.U. 2005, No. 66, item 574)

What is interesting, the translation remained in such cases indifferent to the variety of forms and used the Polish verb equivalent to English verb "mean" ("znaczyć").

\section{Example 5}

"AMENDMENTS TO THE ANNEX of the Convention on Facilitation of International Maritime Traffic, 1965, adopted by the Conference of Contracting Governments on 10 November 1977

Insert in Section 1 - DEFINITIONS AND GENERAL PROVISIONS, SubSection A. DEFINITIONS, the following new definition after the definition of "Mail": 
Passenger in transit. A passenger who arrives by ship from a foreign country for the purpose of continuing his journey by ship or some other means of transport to a foreign country."

(Dz.U. 2005, No. 118, item 988)

Note here unusual format of a legal definition of an international law term "passenger in transit".

Summing up, the translations from Polish and into Polish did not in many cases follow some universal solutions as to the use of particular expressions or typographic conventions (as in drafting guidelines) or used them inconsistently throughout the text. Therefore, a detailed corpus-based qualitative and quantitative analysis would be needed to help establish uniform standards in formulating and translating legal definitions to foster the adequate and consistent interpretation of multilingual instruments.

\section{Conclusions}

What matters in interpreting and translating legal terms is, first of all, proper formulation of legal definitions from formal and logical points of view. This may be determined by such factors as:

- legal system (civil law system, common law system). Cross-cultural differences must be taken into account, for example, that common law definitions are generally more frequent and considerably longer;

- branch of law (civil law, criminal law, international law) where different styles of defining terms are observed;

- type of legal genre (e.g. statutes, contracts, international conventions). Principles regarding statutes are much stricter than those concerning for example contracts. The statutes are governed by national legislative guidelines, being in turn the product of the theory of law and legal doctrine. Even when you translate into Polish the title "Definitions" in a legislative act, this is subject to strict formula in Polish, namely "Objaśnienia określeń ustawowych", which is not the case in contracts;

- position in the legal instrument, i.e. the fact that location of a statutory definition may significantly change its formulation;

- type of legal definition (e.g. extensional vs. intensional definition) and certain universal conventions that are commonly used.

In many aspects contracts and statutes today are subject to the processes of globalization/"Europeanization" and localisation operating upon contemporary legal systems. Sometimes very general terms are used to conform to diverse systems which may lead to the results similar to those produced by the localisation industry. The translation of law terms as defined by EU secondary legislation is adapted to the national legal system of each Member State. This, in turn, affects the construction and the interpretation of the discussed legal genres. The EU law works here as tertium comparationis juxtaposing and combining very different legal systems, cultures and styles. 
On the one hand, the EU legal system inevitably simplifies law (and legal definitions) at the terminological and structural levels, thus also affecting national laws of member states. European drafting techniques place less emphasis on explicit definitions, which reflects a general determination to use ordinary words in an ordinary way wherever possible (Holland and Webb 2006: 222). On the other hand, the EU law introduces, through its legal jargon, new concepts that are structurally difficult to translate, such as "flexicurity" (a term composed through neological process of two lexemes: "(market) flexibility" and "(job) security"), rendered in Polish with a descriptive equivalent "elastyczność i bezpieczeństwo (zatrudnienia)".

Thus, the practice trends of translating law terms is more and more affected by the significance of a still broader context of legal communication rather than confined to the text of a legal instrument itself.

\section{References}

Allot, Antony. 1974. "Law and language in Africa". Zeitschrift für Vergleichende Rechtswissenschaft 74: 124-136.

Arntz, Reiner. 1993. "Terminological Equivalence and Translation". In Terminology. Applications in Interdisciplinary Communication, edited by Helmi B. Sonneveld and Kurt L. Loening, 5-19. Amsterdam/Philadelphia: Benjamins.

Barsalou, Lawrence W. 1992. "Frames, concepts, and conceptual fields". In: Frames, Fields, and Contrasts, edited by Adrienne Lehrer and Eva Feder Kittay, 21-74. Hillsdale, NJ: Lawrence Erlbaum, 21-74.

Bauer-Bernet, Helene. 1982. „Le multilinguisme du droit de la Communauté européenne“. In Langage du droit et traduction, edited by Jean-Claude Gémar, 189205. Montreal: Linguatech/Conseil de la langue française.

Black's Law Dictionary. Garner Bryan A. (ed. in chief) 1992., St. Paul, Minn.: West Group, 7th edition.

Bowers, Frederick. 1989. Linguistic Aspects of Legislative Expression. Vancouver: University of British Columbia Press.

Bromme, Rainer, Bünder, Wolfgang 1994. „Fachbegriffe und Arbeitskontext: Unterschiede in der Struktur chemischer Fachbegriffe bei verschiedenen Nutzergruppen“. Sprache \& Kognition 13: 178-190.

Burch, R. W. 1973. "Cohen, Austin and Meaning”. Ratio 1/XV.

Busse, Dietrich. 1992. Recht als Text: Linguistische Untersuchungen zur Arbeit mit Sprache in einer gesellschaftlichen Institution. Tübingen: Niemeyer.

Charrow, Veda R., Crandall, Jo Ann \& Robert P. Charrow. 1982. "Characteristics and functions of legal language". In Sublanguage. Studies of Language in Restricted Semantic Domains, edited by Richard Kittredge and John Lehrberger, 175-190. Berlin/New York: de Gruyter.

Cornu, Gérard. 1990. Linguistique juridique, Paris: Montchrestien.

Danet, Brenda. 1980. "Language in the legal process" In Contemporary Issues in Law and Social Science, edited by Richard L. Abel, Law and Society Review 14, 445-565.

Driedger, Elmer A. 1976. The Composition of Legislation. Ottawa: Department of Justice. 
Eliot, Thomas Stearns. 1972. Szkice krytyczne. Niemojowska M. (trans. and ed.). Warszawa: PIW.

Engberg, Jan. 2000. "Does routine formulation change meaning? - The impact of genre on word semantics in the legal domain". In Language, Text, and Knowledge: Mental Models of Expert Communication, edited by Lita Lundquist and Robert J. Jarvella, 31-48. Berlin/New York: Mouton de Gruyter.

Friedman, Lawrence M. 1964. „Law and its language“. George Washington Law Review 33: 563-579.

Gadamer, Hans-Georg. 1975. Wahrheit und Methode. (4 ${ }^{\text {th }}$ edition). Tübingen: J.C.B. Mohr.

Garner, Bryan A. 2001. A Dictionary of Modern Legal Usage (2 ${ }^{\text {nd }}$ edition). Oxford: Oxford University Press.

Gémar, Jean-Claude. 1995. Traduire ou l'art d'interpréter, Langue, droit et société: éléments de jurilinguistique, tome 2: Application - Traduire le texte juridique, SaintNicolas (Québec): Presses de l'Université du Québec.

Gotti, Maurizio. 2003. Specialized Discourse. Bern: Peter Lang.

Hart, Herbert Lionel Adolphus. 1958. "Positivism and the separation of law and morals", Harvard Law Review 71/4: 593-629.

- 1961. The Concept of Law, Oxford: Clarendon Press.

Holland, James \& Julian Webb. 2006. Legal Rules (6 ${ }^{\text {th }}$ edition). Oxford: Oxford University Press.

Ignatowicz, Jerzy. 1987. Prawo rodzinne. Zarys wykładu, Warszawa: Państwowe Wydawnictwo Naukowe.

Jahr, Silke. 1993. Das Fachwort in der kognitiven und sprachlichen Repräsentation. Essen: Die blaue Eule.

Joseph, John E. 1995. "Indeterminacy, Translation and the Law". In Translation and the Law, edited by Marshall Morris, 13-36. Amsterdam/Philadelphia: John Benjamins Publishing Company.

Kelsen, Hans. 1967. The Pure Theory of Law. Berkeley: University of California Press.

Kitamura, Ichiro. 1987. "La traduction juridique: Un point de vue japonais". Les Cahiers de droit 28: 747-792.

Lampe, Ernst Joachim. 1970. Juristische Semantik. Bad Homburg v.d.H./Berlin /Zürich: Gehlen, 1970.

Lewison, Kim. 1987. The Interpretation of Contracts. London: Sweet \& Maxwell.

MacCormick, D. N. 1974. "Law as Institutional Fact". Law Quarterly Review 90: 102129.

Malinowski, Andrzej. 2006. Polski język prawny. Wybrane zagadnienia. Warszawa: Wydawnictwo Prawnicze LexisNexis.

— (ed.). 2009. Zarys metodyki pracy legislatora. Warszawa: LexisNexis.

McLeod, Ian. 1993. Legal Method. London: MacMillan.

Mellinkoff, David. 1963. The Language of the Law. Boston: Little, Brown and Company.

Naess, Arne. 1966. Communication and Argument. Oslo: Universitets-forlaget.

Roszkowski, Stanisław. 1999. "The language of law as sublanguage". In: Aspects of Legal Language and Legal Translation, edited by Jerzy Tomaszczyk, 7-16. Łódź: Łódź University Press. 
Rylance, Paul. 1994. Legal Writing and Drafting. Oxford: Oxford University Press.

Sarkowicz, Ryszard. 1995. Poziomowa interpretacja tekstu prawnego. Rozprawy Habilitacyjne No. 290, Kraków: Uniwersytet Jagielloński.

Searle, John R. 1980. "The background of meaning". In: Speech Act Theory and Pragmatics, edited by John R. Searle, Ferenc Kiefer \& Manfred Bierwisch, 221-232. Dordrecht: Reidel.

Stanosz, Barbara. 1973. „Znaczenie a interpretacja”. Studia Semiotyczne IV: 23-33.

Stone, Julius. 1964. The Legal System and Lawyers' Reasoning. Stanford: Stanford University Press.

Šarčević, Susan. 1988. "Translation of legislation - with special emphasis on languages of limited diffusion". In Translation, Our Future. XIth World Congress of FIT, edited by Paul Nekeman, 455-462. Maastricht: Euroterm.

-. 1989. "Conceptual dictionaries for translation in the field of law". International Journal of Lexicography 2/4: 277-293. DOI: 10.1093/ij1/2.4.277

- 1997. New Approach to Legal Translation. The Hague: Kluwer Law International.

Thornton, Garth Cecil. 1987. Legislative Drafting. London: Butterworths.

Tiersma, Pieter M. 2000. Legal Language. Chicago/London: The University of Chicago Press.

Vanderlinden, Jacques. 1995. Comparer les droits. Bruxelles: Story-Scientia.

Wank, Rolf. 1985. Die juristische Begriffsbildung, München: Beck.

Watson, Alan. 1974. Legal Transplants. Edinburgh: Scottish Academic Press.

Weston, Martin. 1991. An English Reader's Guide to the French Legal System. New York/Oxford: Berg.

Wichter, Sigurd. 1994. Experten und Laienwortschätze: Umriss einer Lexikologie der Vertikalität, Tübingen: Niemeyer.

Wunderlich, Dieter. „Methodological remarks on Speech Act Theory”. In: Speech Act Theory and Pragmatics, edited by John R. Searle, Ferenc Kiefer \& Manfred Bierwisch, 291-312. Dordrecht: Reidel, 1980.

Zieliński, Maciej. Wykładnia prawa. Zasady. Reguty. Wskazówki. Warszawa: LexisNexis, 2002.

Ziembiński, Zygmunt. Logika praktyczna. Warszawa: Wydawnictwo Naukowe PWN, 1995.

Zweigert, Konrad \& Hein Kötz. Einführung in die Rechtsvergleichung, vol. I and II (2 ${ }^{\text {nd }}$ edition). Tübingen: Mohr, 1984. 